\author{
SABINA J. HALUPKA-REŠETAR ${ }^{1}$ \\ UNIVERSITY OF NOVI SAD \\ FACULTY OF PHILOSOPHY \\ DEPARTMENT OF ENGLISH \\ ELEONÓRA J. KovÁCS RÁCZ ${ }^{2}$ \\ UNIVERSITY OF NOVI SAD \\ FACULTY OF PHILOSOPHY \\ DEPARTMENT OF HUNGARIAN LANGUAGE AND LITERATURE
}

\title{
ATTITUDES TOWARD ENGLISH: A HUNGARIAN MINORITY CONTEXT IN VOJVODINA, SERBIA
}

ABSTRACT: Although there is abundant literature on attitudes toward English, much less has so far been said about the attitudes of minority language speakers toward a foreign language, especially in contexts in which the minority language speakers receive formal education in their $\mathrm{L} 1$ and are not immersed in an English environment. The paper presents the results of a survey conducted among grammar schools pupils in Vojvodina (Serbia) whose L1 is Hungarian and who have been studying English for over 10 years. There were two groups of research participants, based on the area where they live (compact vs. diffuse language community). The research instrument was a questionnaire, which contained two parts: the first part investigated the participants' profile and the second part explored the participants' value judgements regarding English. The results of the study confirm the initial hypothesis that students living in a diffuse environment will be open to exposure to English and that their attitudes to EFL will be more positive than the attitudes of stu-

\footnotetext{
halupka.resetar@ff.uns.ac.rs

2 kreleonora@ff.uns.ac.rs
}

The paper is the result of research conducted within projects no. 178002 Languages and cultures in time and space and no. 178017 Minority languages, literatures and cultural discourses in Southeast and Central Europe, funded by the Ministry of Science and Technological Development of the Republic of Serbia.

Рад је примљен 14. јануара, а прихваћен за објављивање на састанку Редакције 3борника одржаном 30. марта 2020. 
dents living in a compact environment. Only some of the more general independent variables included in the study show an interaction with positive attitudes towards English. The results of the study lead to pinpointing some determinants of the attitudes Hungarian L1 students in Serbia hold toward English, thereby adding to the scarce literature on minority speakers' attitudes to a foreign language in a multilingual and multicultural area like Vojvodina.

KEYWORDS: language attitudes; attitudes toward English; minority context, compact and diffuse language community.

INTRODUCTION

Owing to the pluricentrality of Hungarian (Lanstyák, 1995), the language use of the Hungarian minority in Vojvodina (Serbia) has been found to display effects which can be traced back to foreign language influence as well as certain dialectal phenomena characteristic of particular geographical regions (Kovács Rácz, 2011b, 2015, p. 117). Previous research into the language attitudes of the Hungarian minority in Vojvodina has mostly focused on local dialects and the influence of other languages with which the Vojvodinian variety of Hungarian comes into contact (primarily Serbian and English). It has been shown (Kovács Rácz, 2011b, p. 331-362) that in addition to Serbian, which is the majority language of the country, Hungarian in Vojvodina also shows signs of language contact with English, which is observed in the subconscious use of English lexemes in the variety of Hungarian spoken in this region. This finding led us to conduct research into attitudes toward English among Hungarian L1 grammar school pupils in Serbia, part of which we present in this paper. As pointed out in Halupka-Rešetar et al. (2018), since Krashen's Affective Filter Hypothesis proposed in 1985, a number of individual factors of affective nature, such as anxiety, motivation and attitudes, have been considered as important prerequisites of successful L2 learning and thus have come into the focus of attention of many applied linguists and L2 acquisition researchers (Csizér and Dörnyei, 2005; Dörnyei, 1994, 2003; Horwitz, 1986, 2001; MacIntyre and Gardner, 1994; Skehan, 1991; Ushioda, 2008 , among others). In other words, students' ability to learn a second (but also a foreign) language can be influenced by their attitudes towards the target language, the target language speakers and their culture, the social value of learning the second language, and also the students' attitudes towards themselves as members of their own culture (Ellis, 1994; Tódor and Degi, 2016). 
The term 'language attitudes' refers to a speaker's subjective opinion held about a particular language or dialect, which reflects their language preference and their positive or negative opinions about the language or language variety (Kiss, 1995, p. 135). Language attitudes have also been defined as 'any affective, cognitive or behavioural index of evaluative reaction toward different language varieties or speakers' (Ryan and Giles, 1982, p. 7), while for Dewaele and Pena Diaz (2018, p. 35) the term refers to speakers' opinions, ideas and prejudices about a language. Garrett et al. (2003, p. 12, as cited in Sallabank, 2013) argue that attitudes to language underpin all manner of sociolinguistic and social psychological phenomena: for example, the group stereotypes by which we judge other individuals, how we position ourselves within social groups, how we relate to individuals and groups other than our own. Attitudes thus represent 'a mental state of alertness which, based on individual experience, triggers a reaction to the phenomena, objects and situations which are the object of attitudes' (Kovács Rácz, 2011b, p. 11). Studies of the role of attitudes in language learning have established that learners who have positive attitudes learn more and that learners who learn well acquire positive attitudes (Atchade, 2002, p. 45). On the other hand, negative attitudes towards the foreign language, which often come from stereotypes and superficial contact with the target culture, can impede the learning of that language. Brown (2000, p. 181) also concludes that "positive attitudes towards the self, the native language group, and the target language group enhanced proficiency' and this reinforces students' positive attitudes, whereas students with negative attitudes may fail to progress and become even more negative in their language learning attitudes (Elyildirim and Ashton, 2006, p. 3). Since attitudes are subject to modification by experience, effective language teaching strategies can encourage students to be more positive towards the language they are learning, which is the main reason for conducting the research described in this paper.

In the sociolinguistic literature on the varieties of Hungarian spoken in the Carpathian Basin, the term 'language attitudes' is used in a wider sense. Kovács Rácz (2011b, p. 11) claims that language attitudes are opinions about a language or language variety, which evaluate the given language or language variety either positively or negatively, while Gréczi-Zsoldos (2011) notes that the term 'language attitudes' refers to a person's subjective attitude towards language forms, the attitude of (a group of) people toward a particular language or language variety, a linguistic phenomenon, linguistic elements and language 
use, and their evaluation of these. Tódor and Degi (2016, p. 123-124) stress that in a larger socio-political, socio-cultural, and socio-economic context, "multilinguals' languages are attributed different meanings and values. Language learners' attitudes towards the language (including its status and prestige) and its speakers greatly influence the language learning process and the learning outcomes".

Foreign language education in Serbia starts in grade 1 of elementary school (pupils aged 7). Thus, at the point of starting grammar school, pupils are expected to have attained level A2 according to the Common European Reference Framework for Living Languages (CEFR). The number of weekly classes in EFL varies between grammar schools, depending on its type: in sciences-oriented grammar schools, less focus is given to languages, while in humanities-oriented grammar schools FL is one of the key subjects. The levels of the pupils' general and individual achievements are defined according to the Common European Reference Framework for Living Languages (CEFR). By the end of the fourth grade of grammar school, pupils are expected to have mastered English as the first foreign language at level B2 (although the productive skills are generally one level lower). However, as pointed out above, proficiency in a second or foreign language is largely conditioned by the age of onset of acquisition but also by the circumstances of language learning. These two factors are claimed to determine our inclination and motivation for learning the foreign language, which results in a positive attitude toward it (cf. Laihonen, 2015, p.47).

Therefore, the aim of the present research is to draw the attention of language educators and researchers to the prevailing attitudes toward English among Hungarian L1 grammar school pupils in Serbia, to identify at least some of the determinants of these attitudes and to suggest ways of improving teaching strategies and educational policy in such a way that pupils who display negative attitudes also achieve an "understanding and appreciation of the foreign culture" (Brown, 2000, p. 181) and consequently, increase their language learning success. Ultimately, (E)FL learners should attain functional-situational bilingualism (multilingualism), which would make their communication in the foreign language much easier and more natural. The reason why we chose 3 rd and 4th year grammar school pupils as participants in this study lies in our belief that their formal education in English and their level of proficiency makes these young adolescents appropriate participants for a study on language attitudes and also 
because we deem that their attitudes largely reflect the quality of EFL teaching in Vojvodina, Serbia.

THE LINGUISTIC LANDSCAPE OF VOJVODINA AND THE HUNGARIAN MINORITY

In Vojvodina, which was once an autonomous region in the southern part of the Austro-Hungarian Empire and is today an autonomous province in the north of Serbia, six languages are used officially: Serbian, the majority language, along with five minority languages Hungarian, Slovak, Romanian, Croatian and Ruthenian. According to Raduški (2003, p. 264), the "[e]thnic complexity of Vojvodina is apparent not only in the high number of different nationalities and their proportion in the population, but also in the spatial distribution of the nationalities, considering the fact that over $80 \%$ of Vojvodina's municipalities are ethnically heterogeneous." Hungarians and Slovaks exhibit spatial polarization and ethnic domination in certain municipalities, while other national minorities are characterized by spatial dispersion and the absence of ethnic domination.

The rights of the national minorities to the use of their mother tongue are regulated by the Bill of Protection of Rights and Freedoms of National Minorities according to which (Article 10) "[m]embers of national minorities can use their language and alphabet freely, both privately and publicly" (as cited in Belić, 2014, p. 12). This means that in areas where national minorities traditionally live and their population reaches $15 \%$, the bill allows the official use of the minority language and alphabet, along with Serbian and Cyrillic alphabet. Various state laws also grant the members of minorities the right to receive education in their mother tongue. Consequently, in Vojvodina, there are currently 71 elementary schools and 35 secondary schools (of which 10 are grammar schools) in which students can receive education with Hungarian as the language of instruction. At the same time, in spite of the multilingual character of Vojvodina, like in many other Central and East European countries, most L1 speakers of the state language display a monolingual attitude (Marácz, 2016, cf. Brubaker et al., 2006).

It is exactly this constellation that is unique to the current research, in which we focus on the language attitudes of the Hungarian minority in a truly exceptional multilingual setting, in which the "hegemonic language, i.e. the official language of the state" (Marácz, 2016, p. 26) is legally not promoted at the expense of so-called minor- 
ity languages and in which the speakers of minority languages have the right to be educated in their L1. On the other hand, Serbian is the state language and it is therefore expected that minority L1 speakers should generally be bilingual. However, a sharp distinction between people living in a diffuse and in a compact environment has already been established in the existing sociolinguistic literature on the Hungarian minority in Vojvodina (Andrić, 2002, 2004, 2006, 2007, 2009, 2012; Bene, 2012; Čudić, 2003; Göncz, 1985, 1991, 1995, 1999, 2004; Grabovac, 2005, 2009, 2010, 2011, 2012, 2013; Grabovac and Pléh, 2014; Láncz, 1996; Mirnics, 2003; Molnár Csikós, 1974, 1995, 1998, 2000; Papp, 2004; Rajsli, 1995, 1996; Vukov Raffai, 2009, 2012; as well as our own research, Kovács Rácz, 2011a, 2011b, 2012a, 2012b, 2015). Namely, a large proportion of young Hungarians living in a compact environment (spatially polarized) in Vojvodina are completely or functionally illiterate in Serbian (cf. Gábrity Molnár, 2007), since they do not speak the language but merely understand (some of) it. Such a situation is mostly the result of the fact that in compact environments, the Hungarian minority lives in homogenous settlements or settlements where Hungarians represent the majority population and are therefore rarely exposed to Serbian except in administrative contexts (Kovács Rácz, 2011b). On the other hand, Hungarians living in a diffuse environment in Vojvodina are in everyday contact with Serbian in a variety of situations and many of them are bilingual. Unlike the compact environment, in the diffuse environment, Hungarian is mostly (or exclusively) used in familial situations. Of course, the situation described here is not unique to Hungarian in a minority context. As pointed out in Dewaele and Pena Diaz (2018), Galician is a co-official language in northern Spain, it is used in local and autonomic administrations, and yet "in general, it is in the rural setting, i.e. in villages and in the coastal areas, that more people use Galician whereas in cities and inland areas Spanish is generally more widely used."

Leaving aside this issue and the potential facilitative effect of bilingualism on learning a new language, in this study we primarily concentrate on the determinants of the Hungarian minority pupils' attitudes towards English, especially on whether these depend on the environment they live in. 
RESEARCH METHODOLOGY

\section{PARTICIPANTS}

The choice of 3rd and 4th grade grammar schools pupils in Vojvodina (Serbia) with Hungarian as the language of instruction as participants in this research is justified by a multitude of reasons. Firstly, to the best of our knowledge, there have so far been no similar studies conducted with grammar school pupils attending Hungarian minority schools in Vojvodina. It is worth mentioning though that Tódor and Degi (2016) studied the attitudes of Hungarian-minority primary and secondary school pupils in Romania to different languages based on their learning experiences. What makes studying the attitudes of the participants in this study interesting is that on the one hand, given that these pupils are speakers of a minority language in Serbia and thus are exposed to the majority language and culture from a fairly young age, the expectation is that they will be open to exposure to English and thus that their attitudes to EFL will be positive. On the other hand, however, pupils who live in a compact environment might show a less positive attitude toward English, much like the attitude they showed toward the majority language (Kovács Rácz and Halupka-Rešetar, 2017). Thus, the environment/ community the informants live in is expected to prove to be an important predictor of their attitudes not only towards their L1 and Serbian, as the majority language, but also towards English. Such an expectation is in line with Dewaele's (2005) study on attitudes towards foreign languages among Flemish high school students, in which a difference was found in attitudes toward French between participants with a strong regional identity (comparable to our participants from a compact environment) and participants with a stronger national identity (comparable to our participants from a diffuse environment), with the former group displaying more negative attitudes.

A total of 423 pupils took part in the research, of which there were 343 participants from six schools in a compact environment, as opposed to a mere 80 participants from the four grammar schools in a diffuse environment (i.e. all 3rd and 4th grade grammar schools pupils in Vojvodina with Hungarian as the language of instruction were included in the study). This significant difference in numbers stems from the fact that around 57\% of the Hungarian population in Serbia live in a compact environment (Barlai and Gábrity, 2008, p. 17), therefore the number of grammar school pupils is also larger in these areas. 
Additionally, the number of Hungarian L1 pupils who decide to attend secondary school in their L1 is not negligible and the compact communities certainly provide more opportunities to do so. Members of the Hungarian minority living in a diffuse environment, on the other hand, often decide to continue their secondary school studies in Serbian, either because this provides them with a wider choice of schools they can apply for or because they believe that attending grammar school in the majority language will prepare them better for their studies at university.

The second reason for choosing exactly these research participants is that their formal education and their expected level of proficiency in English makes them appropriate participants for a study on language attitudes. Thirdly, the attitudes of these young adolescents are expected to reflect the quality of EFL teaching in Vojvodina, Serbia, given that our research participants have been exposed to formal education in EFL for over 10 years. Lastly, but no less importantly, the selection of participants and the research method were strictly limited by the initial permission secured from officials at the schools in which the research was conducted.

\section{INSTRUMENT}

The research method used in this study was a survey and the research instrument was a questionnaire in Hungarian (the participants' L1). The research was conducted in all the grammar schools in Vojvodina in which Hungarian is the language of instruction (10 in total), administered in written form during one regular school class (45 minutes).

The questionnaire was designed specifically for this study, it was first piloted on a group of first-year university students and was partially modified before being used in this large-scale study. It contained two parts: the first part investigated the participants' profile and included questions which addressed issues such as the age of onset of acquisition of English, the frequency of its use, the situations in which the participants use English, their self-assessed proficiency and the grade they were awarded in English at school at the end of the previous academic year. The second part of the questionnaire used a dichotomous scale (yes/no) and it focused on the participants' value judgements regarding English, i.e. on whether they consider English to be a beautiful, useful, easy to learn, necessary to prosper, advantageous and recognized language. Based on the participants' answers to these questions, the study aims to provide a comprehensive picture of the attitudes toward English held by 3rd and 4th year grammar school 
students in Vojvodina whose L1 is Hungarian. Moreover, it is expected to help pinpointing the ways in which the English language competence of Hungarian L1 learners in Vojvodina can be further developed and to enhance the quality of ELT in Vojvodinian grammar schools with Hungarian as the language of instruction, ultimately leading to the pupils attaining functional-situational bilingualism/ multilingualism, i.e. the ability to use multiple languages for special purposes (mostly study, cf. Niemeier, 1999) in a manner appropriate to the particular situation.

\section{RESEARCH DESIGN}

The following independent variables were selected in the present design: a) age of onset of acquisition of English; b) frequency of using English; c) self-assessed proficiency in English; d) contexts of English language use; e) grade awarded at the end of the previous academic year, and $\mathrm{f}$ ) environment (diffuse or compact).

\section{HYPOTHESES}

1) Attitudes towards English will differ depending on environment.

2) Participants from a diffuse environment will have more positive attitudes toward English.

3) Independent variables of a more general nature, such as age of onset of acquisition, frequency of using English, self-assessed proficiency in English, contexts of English language use and school grade in English will affect the participants' attitudes toward English.

\section{RESULTS}

The data obtained within the research are analysed and presented in the following way: for the questions in the first part of the questionnaire, we first give a brief description of the data obtained. Next, the data are analysed using the SPSS Statistics 20 software package to compare the answers of the two groups of participants. Then, the participants' value judgements are analysed and they are correlated with the independent variables listed above in an attempt to establish the extent to which inter-group differences exist in-attitudes toward English (variable ( $\mathrm{f}$ ) above) and whether attitude to English correlates with any of the more general independent variables in (a)-(e) above. 
Proficiency in a second or foreign language is largely conditioned by the age of exposure. However, as Lynch $(2017$, p. 7$)$ stresses, "the contemporary realities of globalism blur the dichotomy traditionally drawn between classroom learning (i.e., language as construct) and social use (i.e., language as practice). This is particularly true in the case of English use among younger-aged, urban, and upwardly mobile populations the world over". People are exposed to English on a daily basis and they acquire it from various sources, often more (successfully) than in an institutional setting. The largest proportion of our research participants (over $42 \%$ of them) said that they had started learning English either at kindergarten (24\% in diffuse and $28 \%$ in compact environment) or at school (35\% in diffuse and $44 \%$ in compact environment). As expected, the percentage of participants who were exposed to English from a very young age is larger among participants from a diffuse environment, which could be the result of various factors, including the size of the city and consequently, the various opportunities it provides. Nonetheless, a comparison of the answers of the two groups of participants (i.e. taking into account the environment in which the participants live and study) returns no statistically significant differences in terms of age of onset of acquisition $(\mathrm{p}=.167-.488)$.

Regarding frequency of using English, over half of the research participants claim to use English on a weekly basis and an additional nearly $30 \%$ said they use it every day, leaving a mere $15 \%$ of those who either use it less frequently or never (or they failed to provide a response to this question). If we take into account the environment the participants live in, we do see some differences between the two populations but the chi-square test shows that overall, and contrary to our expectations, research participants living in a compact environment use English significantly more frequently than those living in a diffuse environment $(\chi 2=7.342, p=.007)$. Possible reasons for this difference are beyond the scope of this research but may well prove to be a fruitful ground for further studies.

Edmondson (1999, p. 143) stresses that "self-assessment is as good an indicator of future proficiency as any others we have going" and he also explores the interrelationship of attitudes, self-assessment (of proficiency) and length of contact (operationalized as age of onset of acquisition in this research). In terms of self-assessment of proficiency in English, judging by the distribution of answers in the total sample, our research participants are rather confident about their proficiency in English: a mere 14 respondents out of 423 admitted to hav- 
ing a rather limited knowledge of English, while the other participants maintained that they can discuss familiar topics in English, with nearly $10 \%$ of the respondents declaring that they are highly proficient users of this language. A comparison of the data per environment shows no significant differences between the two groups of participants with respect to how they assessed their proficiency in English.

Regarding the contexts in which our participants use English, over half of them $(53,2 \%)$ use it in class most frequently. Less than a third of the respondents (27\%) asserted that it is when they travel abroad that they use English most often, whereas the remaining three options available were selected by fewer than $10 \%$ of the participants each. A comparison of the two populations in terms of the answer to this question reveals that the two options mentioned occurred in a larger percentage among participants who live and study in a compact environment but the chi-square test once again shows no significant differences between the two groups of participants.

The fact that school grades in primary and secondary schools in Serbia range from 1 (a fail grade) to 5 (excellent) allowed us to run the Mann-Whitney U test in addition to the chi-square test but it showed no significant differences between the two groups of research participants in terms of the grade awarded at the end of the previous academic year $(\mathrm{p}=.725)$.

In an attempt to establish whether the participants' self-assessed proficiency correlates with their school grade (which might prove to be a relevant piece of information below), we applied Spearman's rank correlation coefficient, which returned a statistically significant correlation between these two variables only in the compact environment, while in the case of participants from a diffuse environment, self-assessed proficiency does not correlate with school grade.

\begin{tabular}{|l|l|l|l|}
\hline $\begin{array}{l}\text { SELF-ASSESSED PROFICIENCY/ } \\
\text { SCHOOL GRADE }\end{array}$ & SPEARMAN'S RHO & P LEVEL & N \\
\hline Diffuse & 0.234 & 0.036 & 80 \\
\hline Compact & 0.009 & 0.867 & 343 \\
\hline
\end{tabular}

TABLE 1: CORRELATION BETWEEN SELF-ASSESSED PROFICIENCY AND SCHOOL GRADE IN ENGLISH

Next, we report on the informants' attitudes toward English, based on their yes/no answers to the statements that English is a beautiful (B)/ useful (U)/ easy to learn (E)/ necessary to prosper (P)/ 
advantageous (A)/ recognized (R) language. In what follows, we first present the answers to these questions (+ or -) in percentages per environment and for the total sample:

\begin{tabular}{|l|l|l|l|l|l|l|l|l|l|l|l|l|l|}
\hline \multirow{2}{*}{$\begin{array}{l}\text { STATEMENTS/ } \\
\text { ENVIRONMENT }\end{array}$} & $\mathrm{B}$ & $\mathrm{U}$ & $\mathrm{E}$ & $\mathrm{P}$ & $\mathrm{A}$ & \multicolumn{3}{|l|}{$\mathrm{R}$} \\
\cline { 2 - 17 } & + & - & + & - & + & - & + & - & + & - & + & - \\
\hline DIfFUSE & 86.3. & 8.8 & 81.3 & 8.8 & 50 & 31.3 & 88.8 & 6.3 & 95 & 1.3 & 97.5 & 2.5 \\
\hline COMPACT & 60.5 & 31.9 & 63.7 & 27.8 & 44.4 & 42.4 & 65.8 & 28.1 & 62.3 & 30.7 & 66.4 & 29.2 \\
\hline TOTAL SAMPLE & 65.4 & 27.5 & 67.1 & 24.2 & 45.5 & 40.3 & 70.1 & 23.9 & 68.5 & 25.1 & 72.3 & 23.7 \\
\hline \hline
\end{tabular}

TABLE 2: DistRIBUTION OF ANSWERS REGARDING VALUE JUDGMENTS OF ENGLISH (TOTAL SAMPLE)

Based on the descriptive statistics in the above table, research participants attending a grammar school in a diffuse environment appear to show a more positive attitude towards English. This difference is largest with respect to the categories 'advantageous' and 'recognized', where pupils studying in a compact environment generally appear to be less willing to acknowledge the significance of English in the 21st century than their peers living and studying in a diffuse environment. This might lead us to the conclusion that there is an interaction between our participants' attitudes toward English (in general) and their environment, which we explored using the Pearson chi-square test of independence for all six statements/value judgements. The results of this analysis confirm a significant interaction with environment in the case of the 'beautiful' $\left(\chi^{2}=19,786\right.$, $p<.000)$, 'useful' $\left(\chi^{2}=12,846, p<.002\right)$, 'necessary to prosper' $\left(\chi^{2}=17,913, \quad p<.000\right)$, 'advantageous' $\left(\chi^{2}=33,606, p<.000\right)$ and 'recognized' $\left(\chi^{2}=32,655, p<.000\right)$, but not for 'easy to learn' $\left(\chi^{2}=3,866\right.$, $\mathrm{p}=.145)$.

If we explore interactions per environment, we obtain the following results: in the diffuse environment, the value judgement 'necessary to prosper' interacts with age of onset of acquisition $\left(\chi^{2}=20,042\right.$, $\mathrm{p}=.029)$, with self-assessed proficiency $\left(\chi^{2}=22,375, p=.004\right)$ and with contexts of use $\left(\chi^{2}=27,575, p=.001\right)$; 'useful' interacts with self-assessed proficiency $\left(\chi^{2}=23,073, p=.003\right)$ and with contexts of use $\left(\chi^{2}=17,587, p=.025\right)$, whereas 'beautiful' interacts with self-assessed proficiency $\left(x^{2}=30,659, p<.000\right)$. In other words, the English language attitudes of our research participants from a diffuse environment depend mostly on their self-assessed proficiency, but also on the contexts of use and (to a lesser degree) on age of onset of acquisition also. 
In the compact environment, interactions are registered between the value judgment 'useful' with age of onset of acquisition $\left(\chi^{2}=20,203, p=.027\right)$ and with self-assessed proficiency $\left(\chi^{2}=16,863\right.$, $\mathrm{p}=.010)$; 'advantageous' with age of onset of acquisition $\left(\chi^{2}=21,752\right.$, $\mathrm{p}=.016)$ and self-assessed proficiency $\left(\chi^{2}=17,899, \mathrm{p}=.006\right)$; 'necessary to prosper' with self-assessed proficiency $\left(\chi^{2}=19,506, p=.003\right)$; 'recognized' with self-assessed proficiency $\left(\chi^{2}=15,674, p=.016\right)$ and 'beautiful' interacts with contexts of use $\left(\chi^{2}=19,573, p=.012\right)$. Thus, in the compact environment, as well as in the diffuse one, the way pupils assess their knowledge of English appears to be the strongest indicator of their attitude toward this language. However, age of onset of acquisition is also identified as a variable that interacts with the participants' value judgements.

Next, we performed a logistic regression test to ascertain the effects of environment, age of onset of acquisition, frequency of use, self-assessed proficiency, contexts of use and grade on the likelihood that participants showed a positive attitude towards English based on their value judgements. Below we give the $\chi^{2}$ value and the significance of the model, the percentage of variance in attitudes the model explained (based on Nagelkerke R square) along with the percentage of cases classified correctly by the model:

\begin{tabular}{|l|l|l|l|l|l|l|}
\hline VALUE JUDGEMENT & $\mathrm{B}$ & $\mathrm{U}$ & $\mathrm{E}$ & $\mathrm{P}$ & $\mathrm{A}$ & $\mathrm{R}$ \\
\hline $\mathrm{x}^{2}$ & 14,402 & 29,892 & 6,520 & 30,815 & 57,618 & 63,955 \\
\hline $\mathrm{p}$ & 0.012 & 0.000 & .368 & .000 & .000 & .000 \\
\hline Variance explained & $9.4 \%$ & $10.9 \%$ & $2.4 \%$ & $11 \%$ & $19.7 \%$ & $21.7 \%$ \\
\hline Percentage correct & $70.4 \%$ & $72.2 \%$ & $56.4 \%$ & $74,6 \%$ & $71.6 \%$ & $73.1 \%$ \\
\hline
\end{tabular}

TABLE 3: RESULTS OF BINARY LOGISTIC REGRESSION

In the case of the value judgement 'beautiful', the variable of environment was the only one that significantly added to the model. Participants from a diffuse environment were 5.32 times more likely to exhibit a positive attitude than participants from a compact environment. Environment also added significantly to the model in the case of 'useful' ( $p=0.001$, with participants from a diffuse environment again being as much as 3.99 times more likely to exhibit a positive attitude than participants from a compact environment), but so did age of onset of acquisition and frequency of use ( $p=0.02$ for both). None of the variables proved to have an effect on the value 
judgement 'easy'. However, environment and age of onset of acquisition were found to correlate with the participants' opinion of English being a language necessary to prosper $(p=0.000$ and $p=0.019$, respectively) and an advantageous language ( $p=0.000$ and $p=0.022$, respectively). In the case of both of these value judgements, participants from a diffuse environment proved to have a more positive attitude toward English. Finally, age of onset of acquisition and frequency of use appear to significantly add to the model in the case of the value judgement 'recognized' $(p=0.013$ and $p=0.037$, respectively), irrespective of the environment.

The above results suggest that Hungarian L1 grammar school pupils in Vojvodina, Serbia, generally share a rather positive attitude toward English. While this is an expected result, the analysis of the data gathered also confirms the initial hypothesis of the research, which was that environment would be an important predictor of attitudes. We expected that pupils from a diffuse environment would show a more positive attitude toward English since these participants are mostly bilingual (Hungarian-Serbian) and it has been proven that knowledge of previous languages affects attitudes towards subsequent foreign languages (Lasagabaster, 2001). This expectation was challenged by our participants from a compact environment, whose answers suggest not only that they are more confident about their proficiency in English but also (probably as a consequence of this) that they use English more often and in a larger variety of contexts than their peers from a diffuse environment. In order to establish whether there is an interaction between our participants' attitudes toward English and their environment, we ran a chi-square test of independence for all six value judgements (English is a(n) beautiful/ useful/ easy to learn/ necessary to prosper/ advantageous/ recognized language). The results confirm a significant interaction with environment regarding all but one statement ('easy to learn'). However, given that the two groups of participants were not balanced in size and since we wanted to explore inter-group differences, we also ran the chi-square test per environment and even though some differences did occur, the way pupils assess their knowledge of English appeared to be the strongest predictor of their attitude toward this language, irrespective of the environment (cf. Dörnyei, 1994, 1998, 2010; Dörnyei and Ushioda, 2011; Edmondson, 1999; Noels et al., 1996; Tremblay and Gardner, 
1995, among others. See also Mikulec and Šamo (2017), who report a negative correlation between self-assessed proficiency in English and positive attitudes towards this language).

Looking at the data from a different perspective, we next performed a logistic regression test to ascertain the effects of the independent variables of age of onset of acquisition, frequency of use, self-assessed proficiency, contexts of use and school grade on the likelihood that participants showed a positive attitude towards English based on their value judgements. The variable of environment proved to significantly add to the model in the case of as many as four of the six value judgements (beautiful, useful, necessary to prosper, advantageous), and so did the variable of age of onset of acquisition (useful, necessary to prosper, advantageous, recognized), whereas frequency of use was only significant for considering English a useful language. These results are in line with previous studies in which the early introduction of English has been shown to exert a positive influence on students' attitudes (see e.g. Cenoz, 2001, 2003; Cenoz and Gorter, 2005, 2017 for Basque students). The effect of the remaining variables on the likelihood that participants showed a positive attitude towards English was not confirmed in this study.

CONCLUSION The present study investigated the language attitudes of 423 Hungarian L1 grammar school pupils in Serbia towards English. The majority of L1 Hungarians in Vojvodina, Serbia, lives in a compact environment and mostly speaks Hungarian, whereas most members of the Hungarian minority who live in a diffuse environment speak Serbian well or are bilingual. This is the reason why one of the initial hypotheses in this study was that a there would be a difference in attitudes towards English between the two groups of participants. We expected that participants from a diffuse environment, already familiar with more than one language, will be more open towards English and more likely to have a positive attitude toward it. We also hypothesized that the independent variables of age of onset of acquisition, frequency of using English, self-assessed proficiency in English, contexts of English language use and school grade in English would also affect the participants' attitudes toward English to varying degrees.

The research hypotheses were mostly confirmed. Namely, the environment the participants live in did prove to interact with their attitude to English, with research participants from a diffuse environment showing a more positive attitude. Of the more general independent variables, self-perceived proficiency in English proved to be 
the strongest predictor of attitudes towards English, but age of onset of acquisition also proved to interact with it, especially in the compact environment, which was a surprising result. The test we ran to ascertain the effects of environment, age of onset of acquisition, frequency of use, self-assessed proficiency, contexts of use and grade on the likelihood that participants showed a positive attitude towards English based on their value judgements also confirmed the initial hypothesis to a large extent: environment was found to correlate with four of the six value judgements, with participants from a diffuse environment showing a more positive attitude towards English than their peers from a compact environment.

There are several limitations to this study, such as the possibility of measurement errors which are beyond the researcher's control (e.g. when participants either do not respond to specific questions, give insufficient answers or do not follow instructions correctly). Also, given that the larger research, which the present study is part of, explored attitudes toward three languages (minority L1, majority L2, EFL), when designing the questionnaire we had to achieve a trade-off: on the one hand, attitudes are a rather complex construct and therefore, to achieve reliable results, exploring them requires a rather elaborate measure i.e. quite a long questionnaire. This becomes an even graver issue when three languages are involved. On the other hand, however, the practical constraints such as getting permission to administer the questionnaire, the teachers' approval to disrupt their classes and the participants' agreement to take part in the research for free impose a significant limitation on the length of the questionnaire and the time needed to fill it in. We therefore conducted a pilot study on the basis of which we modified the questionnaire and made it more user-friendly and less time-consuming.

Regardless of these limitations, the study also has some pedagogical implications. It confirms the finding that early onset of acquisition and having more than one language lead to more positive attitudes toward a new language (in this case, English, cf. Cenoz, 2001, 2003; Cenoz and Gorter, 2005, 2017 for the effect of early introduction of English; also, cf. Lasagabaster, 2001 for the claim that knowledge of previous languages affects attitudes towards subsequent foreign languages). Unfortunately, these are issues which can no longer be altered at grammar school. However, the English language competence of Hungarian L1 learners in Vojvodina can be further developed and improved by insisting on their attaining functional-situational bilingualism/ multilingualism. This can be attained by ensuring that the 
curriculum takes into account the wide range of micro- and macrocontextual and geopolitical factors language attitudes are linked to, and well as unique learner-internal sociobiographical variables and linguistic profiles (cf. Lasagabaster, 2001; Dörnyei et al., 2006; Huguet et al., 2008; Dewaele, 2010; Dewaele and Pena Diaz, 2018). In the context of the research participants in this study, it appears that the macro-contextual factor of environment exerts considerable influence on attitudes: the strong ethnic identity of participants from a compact environment indeed results in a more negative attitude towards English than the more national identity of participants from a diffuse environment (cf. Dewaele, 2005). This suggests that more attention should be paid to stimulating positive attitudes toward language diversity and to fostering plurilingual aspirations in young people generally, but especially so in multilingual contexts like Vojvodina (cf. Busse, 2017).

REFERENCES Andrić, E. (2002). Szerb lexikai hatások a vajdasági magyar nyelvben [Lexical influence of Serbian onto Hungarian in Vojvodina]. Iskolakultúra (12)10. 72-76.

Andrić, E. (2004). A vajdasági magyar gyerekek nyelvhasználatában tapasztalható környezetnyelvi hatásokról [On the influence of the majority language on the language use of Hungarian L1 children in Vojvodina]. In: I. P. Lakatos \& M. T. Károlyi (eds.), Nyelvvesztés, nyelvjárásvesztés, nyelvcsere (153-162). Budapest: Tinta Könyvkiadó.

Andrić, E. (2006). A vajdasági diákok kétnyelvűsége [Bilingualism of pupils in Vojvodina]. Hungarológiai Közlemények, 37(1), 99-115.

Andrić, E. (2007). A szabadkai diákok kétnyelvűsége és magyar nyelvhasználatuk jellemzői [The bilingualism of students in Subotica and the features of their language use]. Hungarológiai Közlemények, 38(2), 52-70.

Andrić, E. (2009). Dvojezičnost mađarskih đaka u Vojvodini [Bilingualism of Hungarian students in Vojvodina]. In: P. Vlahović, R. Bugarski \& Vera Vasić (eds.), Višejezični svet Melanije Mikeš (37-55). Novi Sad: Filozofski fakultet.

Andrić, E. (2012). Az újvidéki középiskolások magyar nyelvi tudatáról [On the language consciousness of Hungarian L1 secondary school pupils in Novi Sad]. Hungarológiai Közlemények, 42(1), 69-84.

Atchade, M. P. (2002). The Impact of Learners' Attitudes on Second or Foreign Language Learning. Revue du Cames - Serie B, 4, 45-50.

Barlai, J. \& Gábrity Molnár, I (eds.) (2008). Hazaérsz. Esély és egyenlőség a Vajdaságban [Homecoming: opportunities and equality in Vojvodina]. Szabadka: Vajdasági Módszertani Központ, Grafoprodukt. 
Belić, B. (2014). Linguistic Vojvodina: Embordered Frontiers. In: T. Kamusella \& M. Nomachi (eds.), The Multilingual Society Vojvodina. Intersecting Borders, Cultures and Identities (1-23). Sapporo: Slavic Research Center, Hokkaido University.

Bene, A. (2012). Vajdaság, egyetem, kétnyelvűség [Vojvodina, university, bilingualism]. In: A. Bene (ed.), A vajdasági magyarok nyelvhasználati szokásairól: Szocio- és pszicholingvisztikai tanulmányok (9-27). Becse: Bene Annamária-Lux Color Printing.

Brown, H. D. (2000). Principles of language learning and teaching. 4th edn. White Plains, NY: Addison Wesley Longman.

Brubaker, R., Feischmidt, M., Fox, J. \& Grancea, L. (2006). Nationalist Politics and Everyday Ethnicity in a Transylvanian Town. Princeton, NJ: Princeton University Press.

Busse, V. (2017). Plurilingualism in Europe: Exploring Attitudes Toward English and Other European Languages Among Adolescents in Bulgaria, Germany, the Netherlands, and Spain. The Modern Language Journal, 101(3), 566-582.

Cenoz, J. (2001). Three languages in contact: Language Attitudes in the Basque Country. In: D. Lasagabaster \& J. M. Sierra (eds.), Language Awareness in the Foreign Language Classroom (37-60). Zarautz: University of the Basque Country.

Cenoz, J. (2003). The influence of age on the acquisition of English: General proficiency, attitudes and code-mixing. In M. P. García Mayo \& M. L García Lecumberri (eds.), Age and the Acquisition of English as a Foreign Language (77-93). Clevedon: Multilingual Matters.

Cenoz, J. \& Gorter, D. (2005). Trilingualism and minority languages in Europe. International Journal of the Sociology of Language, 171, 1-5.

Cenoz, J. \& Gorter, D. (2017). Minority languages and sustainable translanguaging: threat or opportunity? Journal of Multilingual and Multicultural Development, 38(10), 901-912.

Council of Europe. Common European Framework of Reference for Languages (CEFR). Available at: https://www.coe.int/en/web/common-european-framework-reference-languages/level-descriptions

Csizér, K. \& Dörnyei, Z. (2005). Language learners' motivational profiles and their motivated learning behavior. Language Learning, 55(4), 613-659.

Čudić, M. (2003). Prilog izučavanju mađarsko-srpskih jezičkih interferencija u severnoj Vojvodini [Research on Hungarian-Serbian langage interference in northern Vojvodina]. Filološki pregled, 30(2), 187-205.

Dewaele,J.-M. (2005). Sociodemographic, psychological and politico-cultural correlates in Flemish students' attitudes toward French and English. Journal of Multilingual and Multicultural Development, 26, 118-137. 
Dewaele, J-M. (2010). Emotions in Multiple Languages. Basingstoke: Palgrave Macmillan.

Dewaele, J.-M. \& Pena Diaz, C. (2018). Sources of variation in Galician multilinguals' attitudes towards Galician, Spanish, English and French. Revista Nebrija De Lingüística Aplicada a La Enseñanza De Lenguas, 12(25), 34-58. https://doi.org/10.26378/rnlael1225293

Dörnyei, Z. (1994). Motivation and motivating in the foreign language classroom. The Modern Language Journal, 78(3), 273-284.

Dörnyei, Z. (1998). Motivation in second and foreign language learning. Language Teaching, 31(3), 117-135.

Dörnyei, Z. (2003). Attitudes, orientations, and motivations in language learning: Advances in theory, research and applications. Language Learning, 53(1), 3-32.

Dörnyei, Z. (2010). Researching motivation: From integrativeness to the ideal L2 self. In S. Hunston \& D. Oakey (eds.), Introducing applied linguistics: Concepts and skills (74-83). London: Routledge.

Dörnyei, Z., Csizér, K. \& Németh, N. (2006). Motivation, Language Attitudes and Globalisation. Clevedon: Multilingual Matters.

Dörnyei, Z. \& Ushioda, U. (2011). Teaching and researching motivation. 2nd edn. Harlow: Longman.

Edmondson, W. (1999). Twelve Lectures on Second Language Acquisition: Foreign Language Teaching and Learning Perspectives. Tübingen: Gunther Nas Verlag.

Ellis, R. (1994). The study of second language acquisition. Oxford: Oxford University Press.

Elyildirim, S. \& Ashton-Hay, S. (2006). Creating positive attitudes towards English as a foreign language. English Teaching Forum, 44(4), 2-21.

Gábrity Molnár, I. (2007). Vajdasági fiatal magyar diplomások karrierje, migrációja, felnőttoktatási igényei [Career, migration and adult educational needs of young Hungarian graduates from Vojvodina]. In: Karrierutak vagy parkolópályák? Friss diplomások karrierje, migrációja, felnőttoktatási igényei a Kárpát-medencében (132-173). Budapest: MTA Etnikai-Nemzeti Kissebségkutató Intézet.

Garrett, P., Coupland, N., Williams, A. (2003). Investigating language attitudes: Social meanings of dialect, ethnicity and performance. Cardiff: University of Wales Press.

Göncz, L. (1985). A kétnyelvűség pszichológiája [The psychology of bilingualism]. Novi Sad: Forum.

Göncz, L. (1991). A vajdasági magyar-szerbhorvát kétnyelvűség pszichológiai kutatásai [Psychological research into Hungarian-Serbian biligualism in Vo- 
jvodina]. In S. Győri-Nagy \& J. Kelemen (eds.), Kétnyelvűség a Kárpát-medencében II (88-99). Budapest: Széchenyi Társaság.

Göncz, L. (1995). A tannyelv hatása a tanulók személyiségfejlődésére többnyelvü környezetben [The impact of language of instruction on the personality development of pupils in a multilingual environment]. In I. Kassai (ed.), Kétnyelvűség és magyar nyelvhasználat (65-81). Budapest: MTA.

Göncz, L. (1999). A magyar nyelv Jugoszláviában (Vajdaságban) [The Hungarian language of Yugoslavia (Vojvodina)]. Budapest \& Novi Sad: Osiris \& Forum.

Göncz, L. (2004). Újabb nyelvi adalékok a vajdasági magyar beszélők nyelvhasználati szokásaihoz [New additions to the language use of Hungarian speakers in Vojvodina]. In I. P. Lakatos \& Károlyi, M. T. (eds.), Nyelvjárásvesztés és attitűdváltás a vajdasági magyar fiatalok körében. Nyelvvesztés, nyelvjárásvesztés, nyelvcsere. A 13. Élőnyelvi Konferencia előadásai (13-25). Budapest: Tinta.

Grabovac, B. (2005). Emlékezeti szerveződés, nyelvtanulás, fordítás. [Memory organization, language learning, translation]. In E. Csányi (ed.), Társadalom és tudomány (159-173). Novi Sad: Vajdasági Magyar Felsőoktatási Kollégium.

Grabovac, B. (2009). Egynyelvű és kétnyelvű kognitív működés. Integrálás, felzárkóztatás, esélyegyenlőség [Monolingual and bilingual cognitive function. Integration, inclusion, equal opportunities]. In A. Bene (ed.), Az esélyegyenlőség és felzárkóztatás vetületei az oktatásban III (200-212). Novi Sad: Forum / Faculty of Philosophy.

Grabovac, B. (2010). Hasonlóságok és különbségek - egynyelvű és kétnyelvü nyelvi fejlődés és működés [Similarities and differences - monolingual and bilingual language development and functioning]. In A. Bene (ed.), Korszerü módszertani kihívások (154-167). Subotica: Hungarian Language Teacher Training Faculty.

Grabovac, B. (2011). Kétnyelvűség a szemantikus differenciál és a Stroop-teszt tükrében. A magyar nyelv a többnyelvű Vajdaságban, a korszerü európai régiómodellben [Bilingualism in light of the semantic differential and the Stroop-test]. In A. Bene (ed.), A magyar nyelv többnyelvű Vajdaságban I (60-73). Subotica: Hungarian Language Teacher Training Faculty.

Grabovac, B. (2012). Kétszavas érzelmi Stroop-feladat egynyelvű és kétnyelvü vajdasági közegben [A two-word emotional Stroop task in a monolingual and bilingual environment in Vojvodina]. In A. Bene (ed.), A magyar nyelv a többnyelvű Vajdaságban II (56-69). Subotica: Hungarian Language Teacher Training Faculty.

Grabovac, B. (2013). Mérési módozatok a kétnyelvűség-kutatásban és az affektív tudományokban [Measurements in Bilingualism and Affective Science]. 
In J. Berényi (ed.), Tudományos diszkurzusok (83-86). Novi Sad: Vajdasági Magyar Akadémiai Tanács.

Grabovac, B. \& Pléh, Cs. (2014). Emotional activation measured using the emotional Stroop task in early Hungarian-Serbian bilinguals from Serbia. Acta Linguistica Hungarica, 61(4), 423-441.

Gréczi-Zsoldos, E. (2011). A nyelvi attitüd [The language attitude]. Available at: http://www.avorospostakocsi.hu/2011/12/16/a-nyelvi-attitud-2/ (2019. 07. 03.)

Halupka-Rešetar, S., Knežević, Lj., \& Topalov, J. (2018). Revisiting willingness to communicate in English as a foreign language: The Serbian perspective. Journal of Multilingual and Multicultural Development 39/10. 912-924.

Horwitz, E. K. (1986). Preliminary evidence for the reliability and validity of a foreign language anxiety scale. TESOL Quarterly, 20, 559-562.

Horwitz, E. K. (2001). Language anxiety and achievement. Annual Review of Applied Linguistics, 21, 112-126.

Huguet, A., Lapresta, C. \& Madriaga, J. M. (2008). A study on language attitudes towards regional and foreign languages by school children in Aragon, Spain. International Journal of Multilingualism, 5 (4), 175-293.

Kiss, J. (1995). Társadalom és nyelvhasználat [Society and language use]. Budapest: Nemzeti Tankönyvkiadó.

Kovács Rácz, E. (2011a). The use of the dialect among hungarian ethnic minority in Serbia (Banat). In: I. A. Fedorov, L.V. Krasnova \& S.V. Guzenina (eds.), The society, the communities, the human: In search of "eternal world" (105-110). Tambov: Ministry of Education and Science of RF, FSBEI HPE Tambov State University named after G.R. Derzhavin.

Kovács Rácz, E. (2011b). Nyelvi attitüdök a vajdasági magyarság körében [Language attitudes of Hungarians in Vojvodina]. Novi Sad: Sajnos.

Kovács Rácz, E. (2012a). Magyar nyelvjárások az oktatásban [Hungarian dialects in education]. Hungarológiai Közlemények 43(4). 27-37.

Kovács Rácz, E. (2012b). Kisebbségi nyelvjárási attitűd és identitástudat [Minority language attitudes and sense of identity]. In: J. Ispánovics Csapó (ed.), Vajdasági magyar tudóstalálkozó. Tudomány, módszer, argumentáció (35-41). Novi Sad: Vajdasági Magyar Akadémiai Tanács. Available at: http://www.vma t.rs.

Kovács Rácz, E. (2015). A vajdasági magyar ötödik és nyolcadik osztályos tanulók pozitív nyelvjárási attitüdje" [Positive attitudes to dialects among fifth and eighth grade Hungarian pupils in Vojvodina]. Hungarológiai Közlemények 46(3). 114-121.

Kovács Rácz and Halupka-Rešetar. (2017). Korelacija između uzrasta ispitanika, učestalosti upotrebe srpskog jezika, školske ocene i samoprocene znanja 
kod učenika vojvođanskih srednjih škola na mađarskom nastavnom jeziku. Nasleđe 38. 141-161.

Laihonen, P. (2015). A nyelvoktatás elmélete és gyakorlata ma: betekintés a finn oktatásba és azon túl [The theory and practice of contemporary language teaching: education in Finland and beyond. In I. Vančo \& I. Kozmács (eds.), Nyelvtanulás - nyelvtanítás. Fókuszban az államnyelv oktatása kisebbségek számára (43-56). Nyitra: Nyitrai Konstantin Filozófus Egyetem.

Láncz, I. (1996). A köznyelvűsödés útján [On becoming common language]. In: I. Láncz (ed.), Nyelvünk - nyelvhasználatunk (43-53). Budapest: Betli Bt.

Lanstyák, I. (1995). A magyar nyelv központjai [The linguistic centres of Hungarian]. Magyar Tudomány, 10, 1170-1185.

Lasagabaster, D. (2001). University students' attitudes towards English as an L3. In: J. Cenoz, B. Hufeisen \& U. Jessner (eds.), Looking beyond Second Language Acquisition (43-50). Tübingen: Stauffenburg Verlag.

Lynch, A. (2017). Bilingualism and Second Language Acquisition. In: N. Van Deusen-Scholl \& Nancy H. Hornberger (eds.), Second and Foreign Language Education, Encyclopedia of Language and Education vol. 4 (43-55). Cham: Springer International Publishing.

MacIntyre, P. D. \& Gardner, R. C. (1994). The Subtle Effects of Language Anxiety on Cognitive Processing in the Second Language. Language Learning, 44, 283-305.

Marácz, L. (2016). Empowering ethno-linguistic minorities in Central- and Eastern Europe. Belvedere Meridionale, 28 (2), 21-37.

Mikulec, A. \& Šamo, R. (2017). How important is English to Croatian pre-service primary and preschool teachers not majoring in English? In: S. Letica Krevelj \& R. Geld (eds.), UZRT 2016: Empirical Studies in Applied Linguistics (115-126). Zagreb: FF Press.

Mirnics, K. (2003). Nemzeti kisebbségből szórványnépesség. In: I. Molnár Gábrity \& Zs. Mirnics (eds.), Kisebbségi létjelenségek (25-84). Szabadka: MTT Könyvtár 7.

Molnár Csikós, L. (1974). Szociolingvisztikai vizsgálatok a Dunatájon [Sociolinguistic research along the Danube]. Létünk, 4(5-6), 76-83.

Molnár Csikós, L. (1995). A vajdasági magyar diáknyelv napjainkban [The language of Hungarian pupils in Vojvodina]. Híd, 59, 347-351.

Molnár Csikós, L. (1998). Az anyanyelven való tanítás a jugoszláviai magyarok körében [Teaching in the mother tongue among Hungarians in Yugoslavia]. In: I. Molnár Gábrity \& Zs. Mirnics (eds.), Vajdasági útkereső (191196). Szabadka: MTT Könyvtár 2.

Molnár Csikós, L. (2000). Vajdasági diákok nyelvhasználati viselkedése [The language use of pupils in Vojvodina]. In: A. Borbély (ed.), Nyelvek és kultúrák 
érintkezése a Kárpát-medencében. A 10. Élőnyelvi Konferencia előadásai (157-163). Budapest: MTA Nyelvtudományi Intézet.

Niemeier, S. (1999). A Cognitive View On Bilingualism And “Bilingual” Teaching And Learning. Journal of English Studies, I, 165-185.

Noels, K. A., Pon, G. \& Clément, R. (1996). Language, identity, and adjustment: the role of linguistic self-confidence in the acculturation process. Journal of Language and Social Psychology, 15(3), 246-264.

Papp, Gy. (ed.). (2004). Mi ilyen nyelvben élünk [The language we live in]. Szabadka: MTT Könyvtár 9.

Rajsli, I. (1995). Nyelvi adaptálódás és kódváltás a megváltozott körülmények között [Language adaptation and code switching under altered circumstances]. In: I. Kassai (ed.), Kétnyelvűség és magyar nyelvhasználat. A 6. Élőnyelvi Konferencia előadásai (299-305). Budapest: Az MTA Nyelvtudományi Intézetének Élőnyelvi Osztálya.

Rajsli, I. (1996). A kódváltás jelensége a fiatalok nyelvhasználatában [Code switching in the language use of young people]. Ada: Szarvas Gábor Nyelvmüvelö Napok. 68-73.

Ryan, E. B. \& Giles, H. (1982). Attitudes towards language variation. London: Arnold.

Sallabank, J. (2013). Endangered Languages: Attitudes, Identities and Policies. Cambridge: Cambridge University Press.

Raduški, N. (2003). Etnička slika Srbije - popis 2002. godine [The ethnic picture of Serbia - the 2002 census]. Migracijske i etničke teme, 19(2-3), 253-267. Available at https://hrcak.srce.hr/7860 (2019.07. 03.)

Skehan, P. (1991). Individual differences in second language learning. Studies in Second Language Acquisition,13(2), 275-298.

Tódor, E. \& Degi, Zs. (2016). Language Attitudes, Language Learning Experiences and Individual Strategies What Does School Offer and What Does It Lack? Acta Universitatis Sapientiae, Philologica, 8(2), 123-137.

Tremblay, P. F. \& Gardner, R. C. (1995). Expanding the motivation construct in language learning. Modern Language Journal, 79(4), 505-520.

Ushioda, E. (2008). Motivation and good language learners. In: C. Griffiths (ed.), Lessons from good language learners (19-34). Cambridge, UK: Cambridge University Press.

Vukov Raffai, É. (2009). A kétnyelvűség megítélése kétnyelvű környezetben [The perception of bilingualism in a bilingual environment]. In: A. Borbély, I. Vančóné Kremmer \& H. Hattyár (eds.), Nyelvideológiák, attitűdök és sztereotípiák. 15. Élőnyelvi Konferencia. Budapest-Dunaszerdahely-Nyitra: Tinta Könyvkiadó.

Vukov Raffai, É. (2012). Az örökíró, a hémijszka, és ami körülöttük van. Subotica: Grafoprodukt. 


\section{САБИНА ХАЛУПКА-РЕШЕТАР}

УНИВЕРЗИТЕТ У НОВОМ САДУ

ФИЛОЗОФСКИ ФАКУЛТЕТ

ЕЛЕОНОРА КОВАЧ-РАЦ

УНИВЕРЗИТЕТ У НОВОМ САДУ

ФИЛОЗОФСКИ ФАКУЛТЕТ

РЕЗИМЕ

\section{СТАВОВИ ПРЕМА ЕНГЛЕСКОМ ЈЕЗИКУ: \\ КОНТЕКСТ МАЪАРСКЕ МАҢИНЕ У ВОЈВОДИНИ}

Иако постоји обимна литература о ставовима према енглеском језику, до сада су у значајно мањој мери истраживани ставови говорника мањинских језика према страном језику, посебно у контекстима у којима говорници мањинског језика стичу формално образовање на свом језику и нису изложени страном језику у непосредној околини. У раду су представљени резултати анкете спроведене међу ученицима гимназија у Војводини (Србија) чији је матерњи језик мађарски и који енглески језик уче више од десет година. У истраживању смо имали два подузорка испитаника, зависно од окружења у ком живе (компактна и дифузна језичка заједница). Истраживачки инструмент био је упитник који је садржавао два дела: први део је истраживао профил учесника, а други је истраживао вредносне судове учесника о енглеском језику. Почетне хипотезе истраживања биле су (1) да ће окружење у коме испитаници живе утицати на њихове ставове према енглеском језику, (2) да ће испитаници из дифузног окружења изразити позитивнији став према енглеском језику од испитаника који живе у компактном окружењу, те (3) да ће варијабле општије природе, као што су узраст у коме су почели да уче енглески језик, учесталост употребе овог језика, самопроцена знања енглеског језика, контексти његове употребе и школска оцена из предмета Енглески језик такође утицати на ставове испитаника порема енглеском језику као страном.

Резултати истраживања потврђују почетну хипотезу да окружење утиче на ставове: испитаници који живе у дифузном окружењу показали су се отворенијим за излагање енглеском језику и њихов однос према овом језику се такође показао позитивнијим од ставова испитаника који живе у компактном окружењу. Само неке од општијих независних варијабли укључене у студију показују интеракцију са позитивним ставовима према енгле- 
ском језику. Наиме, самопроцена знања енглеског језика показала се као најјачи предиктор односа према енглеском језику, али се показала интеракција са узрастом у коме су испитаници почели да уче енглески језик, посебно у компактном окружењу, што је било изненађујуће. Тест који смо спровели како бисмо утврдили утицај ових варијабли на вероватноћи да су учесници показали позитиван став према енглеском на основу њихових вредносних судова такође је у великој мери потврдио почетну хипотезу: окружење корелира са четири од укупно шест вредносних судова, при чему су испитаници из дифузног окружења показали позитивнији став према енглеском језику него њихови вршњаци из компактног окружења.

Упркос ограничењима, пре свега у погледу обимног истраживачког инструмента, броја недостајућих одговора на упитницима, те ограниченог приступа испитаницима, овде представљена студија такође има одређене педагошке импликације. Пре свега, потврђује већ познату чињеницу да учење/усвајање језика на раном узрасту и билингвизам/мултилингвизам резултују позитивнијим ставовима према новом језику (у овом случају, према енглеском, уп. Cenoz, 2001, 2003, Cenoz and Gorter, 2005, 2017, Lasagabaster, 2001). И мада се на ове факторе не може утицати у гимназији, компетенције ученика енглеског језика из Војводине, чији је матерњи језик мађарски могу се даље развијати и побољшавати инсистирањем на њиховом постизању функционално-ситуационе двојезичности/вишејезичности. Ово се може постићи уколико се у наставни план и програм укључи читав спектар микро- и макроконтекстуалних и геополитичких фактора који су повезани са језичким ставовима, као и јединствене социобиографске варијабле и језичке профиле ученика (уп. Lasagabaster, 2001, Dörnyei et al., 2006, Huguet et al., 2008, Dewaele, 2010, Dewaele and Pena Diaz, 2018). У контексту испитаника у овој студији, чини се да макроконтекстуални фактор окружења има значајан утицај на ставове: изражен етнички идентитет испитаника из компактног окружења доводи до негативнијег односа према енглеском језику од националног идентитета карактеристичнијег за испитанике из дифузног окружења (уп. Dewaele, 2005). Ово наводи на закључак да много више пажње треба посветити подстицању позитивног става према језичкој разноликости код младих, као и неговању вишејезичних аспирација, нарочито у вишејезичним контекстима каква је Војводина (уп. Busse, 2017). Резултати овог истраживања 
требало би да допринесу оскудној литератури о ставовима мањинских говорника према страном језику у вишејезичним и мултикултурним областима попут Војводине.

КључнЕ РЕчи: језички став; ставови према енглеском језику; мањински контекст; компактна и дифузна језичка заједница.

Овај чланак је објављен и дистрибуира се под лиценцом Creative Commons Ауторство-Некомерцијално Међународна 4.0 (СC BY-NC 4.0 |

https://creativecommons.org/licenses/by-nc/4.0/).

This paper is published and distributed under the terms and conditions of the Creative Commons Attribution-NonCommercial International 4.0 licence (CC BY-NC 4.0 | https://creativecommons.org/licenses/by-nc/4.0/). 